\section{On forgetful goldfish and failed mnemonics: transforming political economies of conflict using voluntarism, regulation, and supervision}

Neil Cooper

"[M]any international workers ... speak privately about the futility of their missions; of having impacts as lasting as training goldfish.” William Reno (2008, p. 390).

$\mathrm{O}$ ne of the features of the post-cold war era has been a remarkable growth in academic and policy attention devoted to the role played by economic actors and economic agendas in the inception and perpetuation of civil conflicts as well as in shaping the prospects for postconflict peacebuilding. This has incorporated a large and diverse range of themes ranging from the trading of specific conflict goods, the conflict dynamics resulting from the interaction of greed, feasibility, and grievance factors at the local level, the broader economic and governance challenges arising from what has been labeled the resource "curse," and the even broader challenges produced by the interaction of local, regional, and global economic structures. ${ }^{1}$

This diversity of themes has also been reflected in the production of a rather disparate set of policies aimed at transforming economies of conflict. Indeed, a feature of these policies is that they have mostly been produced as subsets of other initiatives (e.g., environmental sustainability, good governance, poverty reduction, anticorruption, corporate social responsibility). One of the first observations to be made about the challenge of transforming war economies then, is that while it is widely recognized as a vital element in resolving conflicts, the universe of potentially relevant policy action is so diffuse, and so disaggregated into other policy arenas, that there is a sense in which it does not really exist as a discrete field of policy in its own right.

On one view, this dissipation into other policy frameworks does not really matter as issues of good governance, anticorruption, etc. all are integral elements of a broader liberal peace project capable of transforming war economies via the export of democracy, rights, and free markets. There is also a sense, even in much of the more critical literature, that while the technicalities of specific policies may need refinement, the broad reform agenda on issues such as ethical trading or anticorruption is nevertheless part of a progressive liberal history of ethical global regulation under which the range of issues tackled has gradually widened and the frameworks of ethical regulation have become ever deeper or more substantive. The remainder of this article is devoted to challenging these assumptions. In particular, three sets of initiatives are examined that are most closely associated with the task of transforming war economies: voluntary ethical trading schemes, formal or de facto regulation to promote ethical trading or good resource governance, and economic supervision schemes.

The mainstream literature is characterized by a heated debate over the relative weight that should be given to these approaches, with voluntarism and formal regulation, in particular, often characterized as mutually exclusive options. In essence however, this represents a debate over what constitutes the best strategy to achieve a common goal: to set a framework that balances the pursuit of business (whether conducted to make profit, make war, or simply make-do in situations of acute poverty) against the broader economic and nonmaterial needs of individuals, societies, states, and the global system as a whole, and to do so in a context that takes liberal market precepts as a given. In short, the aim is deemed to be the creation of a more harmonious and pacific liberal political economy. Thus, the task of voluntarism, regulation, or economic supervision is simply to get economic actors operating under the imperatives of market logic to remember they have a broader social responsibility rather than succumbing to the regular temptations of narrow profit-making and the functional amnesia it can generate. As in the quote at the start of this article from William Reno's critique of economic supervision in Liberia, the common task is assumed to be akin to training goldfish to remember. To the extent that there is a disagreement it is principally over how widespread and how profound the predilection for amnesia is, how easy it is to bring back memory, and of course exactly where the point of harmony in a political economy of peace is located. In contrast, the final section of this article suggests that what is more striking from a critical political economy perspective is the way in which discourse and practice effectively works to obscure the recycling of failed policies, the retreat from more ambitious forms of ethical regulation and the absence of substantive action.

\section{Voluntary ethical trading schemes}

The post-cold war era has witnessed an explosion in voluntary ethical trading 
schemes. Proponents of voluntarism emphasize the difficulties involved in persuading states and companies to agree binding regulation, noting that the nonbinding nature of voluntary initiatives makes them more attractive to such actors and thus far more likely to be adopted. At the same time, they also adopt an essentially optimistic view of both the scale of ethical amnesia to be addressed and the ease with which memory can be restored. The logic underpinning voluntarism is either that the peer and civil society pressure exerted via nonbinding commitments are sufficient to remind the majority of companies and governments of the need to trade responsibly, or alternatively, that voluntarism can act as a stepping stone toward formal regulationa kind of ethical mnemonic adopted in order to get to the full moral memory of formal regulation.

Advocates of voluntarism are also relatively optimistic about the ease with which the demands of profit-making can be reconciled with some kind of ethical trading framework. Indeed, on this view, ethical trading represents a form of enlightened self-interest on the part of economic actors who have just as much interest as consumers in ensuring strong states, law and order, wealthy customers, and brand loyalty. For example, a number of empirical studies have suggested a positive relationship between socially responsible behavior and the financial performance of companies. $^{2}$

Critics highlight the way in which voluntary initiatives tend to be characterized by nonexistent or anaemic monitoring of compliance and little in the way of sanctions for noncompliance. The United Nations' Global Compact (GC), launched in 2000, is typical in this respect. It seeks to align business operations with a voluntary set of principles covering areas such as human rights, labor standards, the environment, and (since 2004) anticorruption. With a membership that includes over 4,700 businesses from 120 countries, it has been described as "the world's largest corporate social responsibility initiative" and as offering companies "one-stop shopping [on] ... human rights, environment and labor standards, thereby reducing their transaction costs." But with an estimated 77,000 transnational firms with some 770,000 subsidiaries the scheme still only covers a minority of firms. Moreover, participation merely requires companies to publicly advocate for the $\mathrm{GC}$, produce a communication on progress outlining how the company is working to advance the GC, and participate in GC policy dialogues - one of the earliest of which was on the role of business in zones of conflict. Crucially however, the arrangements to monitor claims made by companies in their Communication of Progress are limited to a provision introduced in 2005 under which third parties can report serious violations of Compact principles to the GC office. While this can prompt negotiations within the GC, complainants are prevented from making public statements until the issue is resolved. Despite these quite limited obligations, the GC's Annual Review for 2007 nevertheless recorded nearly a third of participants as either noncommunicating or inactive, and a 2004 study found that only 6 percent of participating companies were undertaking actions they would not have taken if they had remained outside the initiative. ${ }^{3}$
Perhaps a more fundamental criticism of the GC is that its very existence allows companies to resist calls for formal regulation by pointing to the action supposedly being undertaken as a result of voluntarism. This criticism can also be leveled at the Extractive Industries Transparency Initiative (EITI), a voluntary multi-stakeholder initiative that includes donor governments, civil society, producer countries, and companies in the extractive sector. The aim of EITI is to promote revenue transparency in the extractive sector through double parallel disclosure of payments by both host governments and companies. The underlying assumption is that transparency will deter the corrupt use of resource payments thus ensuring that money is used for the benefit of local populations and in ways more likely to maximize the developmental impact of natural resource wealth. EITI includes 37 of the world's largest oil, gas, and mining companies and 23 EITI candidate countries. The latter are required to implement EITI processes that include publishing information on state revenues from the extractive sector and engaging with a national stakeholder group. If certified as compliant by an EITI Validator, countries are then labeled as an EITI Compliant country. At the time of writing, no country has yet been validated by EITI although it is expected that Azerbaijan and Nigeria will achieve this status soon. In response to criticism that the EITI focuses on just one part of the revenue chain - company payments to governments - the World Bank has, in addition, sponsored a separate program, labeled EITI++, which aims to cover the entire resource chain from extraction, processing, and managing revenues to promoting sustainable utilization of resource wealth.

The voluntary nature of EITI means that membership remains patchy; only one of the word's top ten oil producers (Norway) and only one OPEC country (Nigeria) is a member of EITI. Moreover, the record of many candidate countries is not inspiring: Nigeria has failed to comply with legal requirements to audit 2006 and 2007 extractive industry revenues, and in 2008 the former head of the company Kellogg Brown and Root (now KBR) pleaded guilty to providing USD180 million in bribes to Nigerian officials between 1995 and 2004. In Iraq, another EITI country, Judge Rahdi, a leading anticorruption official has fled the country in fear of his life while only Burma and Somalia have a worse ranking in Transparency International's Corruption Perception Index. Furthermore, while the World Bank may have sponsored EITI++, one 2008 survey found that it only designated transparency as a program benchmark in 19 percent of country lending programs and that 90 percent of World Bank operations in resource-rich countries failed to promote contact disclosure. The key problem with the EITI however, as noted above, is that it can be understood as a voluntary, and thus weaker, alternative to calls for more rigorous formal regulation, in particular the "publish what you pay" (PWYP) campaign to make the listing of companies on stockmarkets contingent upon transparent publication of all payments to national governments. ${ }^{4}$ 


\section{Formal regulation}

The perceived failings of voluntarism have spurred calls for more formal regulation and/or de facto regulation via the creation of strong international regimes to address the different dimensions of war economies. Such calls have largely come from an NGO sector that has tended to hold a pessimistic conception of both the scale of ethical amnesia on the part of economic actors and the severity of the tension deemed to exist between the pursuit of profit and the broader economic and social responsibilities of such actors. For these proponents of formal regulation, market logic creates particularly strong imperatives for amnesia that require equally strong mechanisms of monitoring and enforcement if economic actors are to be persuaded to resist the siren temptations of functional forgetfulness.

Formal regulation is usually viewed, by supporters and opponents alike, as an ethical high water mark, even where commentators advocate some mix of voluntarism and regulation as the most pragmatic and effective means of promoting responsible business practices. Examples of formal regulation include national regulations such as the United States' Alien Torts Claims Act which allows companies to be sued at home for their behavior abroad; United Nations commodity sanctions imposed on actors in conflict, and multilateral initiatives such as the OECD 1997 Convention on Combating Bribery. An example of a relatively strong regime is the Kimberley Process Certification Scheme (KPCS) agreed in 2002 to prevent the trade in conflict diamonds. At the heart of the scheme is a requirement for participating governments to issue a certificate for each parcel of rough diamond exports declaring them to be conflict-free and for importing countries to only accept rough diamonds when accompanied by such certificates. Although Kimberley is a voluntary multi-stakeholder initiative, it nevertheless involves members enacting domestic legislation to support the scheme and it can punish noncompliance by expulsion. Given that the scheme involves all the major rough diamond producing, exporting, and importing companies and countries this is, in theory at least, quite a severe sanction. Indeed, for supporters this means that "in real terms it is compulsory." With the ending of sanctions on Liberia (see below) the only remaining example of conflict diamonds as defined by Kimberley are those exported from the rebel-held areas of Côte d'Ivoire. This trade, under U.N. sanction since 2005, has been valued at between USD12 and USD21 million annually, thus allowing the Kimberley Process to claim that conflict diamonds account for less than 0.1 percent of world production. ${ }^{5}$

Nevertheless, even formal and de facto regulatory approaches suffer from a number of weaknesses. For example, like action on conflict trade more generally they can be criticized as shaped by a "drugs, thugs and rocks" bias that primarily targets nonstate actors such as rebel groups, specific rogue states, and particular pariah goods (drugs, conflict diamonds) rather than the phenomenon of conflict trade or war economies per se. Thus, one study examining 26 conflicts involving resources in the period 1989-2006 found United Nations commodity sanctions were used on only seven occasions. Formal regulation and regime development also tend to occur within a security (e.g., antiterror) or policing and law and order framework that fails to address the political economies driving involvement in shadow trade and underpinning civil conflict. More generally, initiatives have also been criticized as being shaped by the interests of developed world actors, predominantly aimed at the developing world, and underpinned by crude representations of postcolonial states as arenas of poor governance and endemic corruption.

The Kimberley Process Certification Scheme embodies many of these criticisms For example, while the regime, which came into operation in January 2003, is ostensibly designed to prevent the trade in conflict diamonds, it operates under a restrictive definition that describes them as "rough diamonds used by rebel movements or their allies to finance conflict aimed at undermining legitimate governments as described in relevant United Nations Security Council (UNSC) resolutions." Consequently, even as it aims to prevent the trade in conflict diamonds, KPCS does not necessarily prevent the trade in diamonds from conflicts-either because the definition excludes both the trade in polished diamonds and trade conducted by "legitimate governments" or because the trade has not, anyway, been subject to U.N. sanction. As Kimberley has evolved, actual practice has tended to exacerbate such definitional problems. ${ }^{7}$

For instance, diamond sanctions imposed on Charles Taylor's Liberia in 2001 were not only continued for four years after his eviction and the formation of a transitional government in 2003 but for over a year after a new democratically elected government came to power in January 2006. This was on the grounds that although conflict was over, it was necessary to keep sanctions in place until Liberia improved governance of the diamond sector. Consequently, Liberian diamonds were effectively treated as conflict diamonds by the Kimberley Process. More recently there has been growing pressure for Kimberley to go beyond the formal definition of conflict diamonds and take action against particular pariah states whose governance of the diamond sector has been criticized. Most notably, NGOs such as Global Witness and Partnership Africa Canada have called for the expulsion of Zimbabwe following reports of human rights abuses committed against informal diamond miners and subsequent government collusion in the illicit diamond trade from Maranga, close to the border with Mozambique. In January 2009, the European Union also urged the Kimberley Process to probe Zimbabwe's diamond trade, and in March 2009 a highlevel envoy team was dispatched by the Kimberley Process to express its concerns to the government of Zimbabwe. To date, Zimbabwe has not been expelled from Kimberley, although in April 2009 the World Federation of Diamond Bourses did call on all members to ensure that they did not trade in diamonds from Maranga (although not other diamond producing areas in Zimbabwe).

For critics, the failure to take stronger action against Zimbabwe has highlighted the weaknesses of the regime. At the same time the willingness to stretch the 
definition of conflict diamonds in the case of pariahs such as Zimbabwe is notably at odds with action toward other actors. For example, diamond exports from the Democratic Republic of the Congo (DRC) - even by nonstate domestic actors or regional neighbors such as Uganda or Rwanda-have never been subject to a U.N. ban and thus never been labeled as conflict diamonds. Similarly, the Israeli government recorded net exports of polished diamonds (after returns) of USD6.6 billion in 2006 and net exports of rough diamonds of USD2.7 billion. Separate Kimberley Process data recorded a slightly higher figure for rough diamond exports of USD3.5 billion, making Israel the world's largest exporter of rough diamonds in 2006. In total, official net diamond exports accounted for almost 15 percent of goods and services exported from Israel in 2006, thus making a significant contribution to the Israeli war economy. Yet despite the ongoing Israeli-Palestinian conflict, Israel's continued breach of U.N. resolutions, and its 2006 war in Lebanon, neither its polished or rough diamond exports were (or are) deemed to be conflict diamonds by either the United Nations or the Kimberley Process. Instead, Israel has been elected as Deputy Chair of the Kimberley Process for $2010{ }^{8}$

A further problem with regard to Kimberley is that it was primarily established to address the issue of conflict diamonds via a system of policing and monitoring, rather than to address the broader political economies of diamond production that contributed to the production of conflict economies in the first place. For supporters, Kimberley has, nevertheless, produced important developmental benefits. For example, while Kimberley only came into being after the end of conflicts such as those in Sierra Leone or Angola, it is argued that NGO campaigns on conflict diamonds and the subsequent negotiations on Kimberley provided a deterrent effect that restricted the ability of rebel groups to raise funds, thus contributing to the peace necessary to spur development. It is also argued that certification has produced marked rises in official exports from such states, thus raising the tax revenue also necessary to promote development. Moreover, the absence of a formal development component in Kimberley itself has been addressed via the creation in 2005 of the Development Diamond Initiative (DDI), a separate but complementary multi-stakeholder effort involving many of the same industry and NGO actors associated with Kimberley. The aim of DDI is to "optimize the beneficial development impact of artisanal diamond mining to miners and their communities." In addition, donors such as the United Kingdom and the United States have promoted various initiatives (e.g., the creation of cooperatives in Sierra Leone) aimed at addressing the exploitation of diggers and improving governance of the diamond sector in postconflict states. ${ }^{9}$

However, the experience of postconflict Sierra Leone illustrates the development deficiencies in this broader conflict/development diamond regime. First, donor initiatives to address the pay and conditions of diggers have mostly been tokenistic and short-term. Thus only five cooperative projects involving 50 to 70 people were implemented in an industry estimated to involve at least 120,000 diggers, and even these have now ceased. Similarly, while the DDI has produced a number of reports on the conditions of diggers, it has, to date, resulted in few concrete projects. Diggers in Sierra Leone therefore continue to earn an estimated one to two U.S. dollar a day while in 2005 the country's top three exporters officially transferred diamonds worth USD105 million. Second, although the government's tax take from diamond exports has risen, this amounted to just USD5.2 million in 2004 and is constrained by the fact that higher taxes stimulate shadow trade across porous borders. In neighboring Liberia, government revenue from the now sanction-free diamond sector is predicted to be just USD500,000 to USD750,000, enough to cover the costs of implementing Kimberley but little else. Third, while smuggling certainly remains a problem for countries like Sierra Leone, its principal problem is arguably the phenomenon of capital flight which has meant that "hardly any of the profits generated by the diamond sector are reinvested in Sierra Leone." Fourth, neither Kimberley nor the DDI addresses the fact that the economic returns from Sierra Leone's diamond sector are limited as a result of the way value is added elsewhere in the global diamond economy. For example, one estimate for 2007 calculated that while the global value of rough diamond production amounted to USD12.5 billion, the value after polishing was USD19 billion, after going through the jewelry wholesale pipeline it increased further to USD30 billion and finally amounted to some USD70 billion in the jewelry retail sector. $^{10}$

A combined conflict/development diamond regime that responds to the structural exploitation inherent in the global diamond industry with acts of ethical tokenism is perhaps best understood as a simulation of an ethical trading regime rather than a substantive manifestation of one. Similarly, a conflict diamond regime that permits Israeli diamond exports in the middle of its war in Lebanon while simultaneously proscribing diamond exports from postconflict Liberia is best described as a disciplinary tool directed against nonstate actors and weak and pariah states, rather than one aimed at the phenomenon of conflict diamonds per se.

Economic supervision: amnesia meets polyphasia

The third approach to the interrelated problems of conflict trade, the resource curse, and the challenge of transforming war economies has been to use various forms of economic supervision to address the economic agendas of actors during conflict or 
to improve economic governance during peace. This has most commonly occurred when donors have been able to take advantage of a state's permanent or temporary dependence on external funds or troops to impose forms of oversight or guidance that significantly undermine the sovereign powers of a particular aid or security supplicant - albeit with the aim of transforming war economies. Such initiatives are underpinned by acutely pessimistic assumptions about the willingness of local political elites to engage in ethical amnesia. Indeed, there is often an assumption that corruption and exploitation are so widespread and ingrained as to be intrinsic to the political economy of society, in short, that there is not much in the way of ethics to forget in the first place. At the same time, it is also assumed there is a latent demand among the general population for liberal forms of political and economic governance that is simply waiting to be released. The solution advocated therefore is emergency external oversight to deter and detect abuse combined with radical projects of societal transformation (e.g., capacity building, civil society empowerment) aimed at reforming elites, releasing pent-up demand, and thus preventing or demobilizing war economies.

The most cited example of economic supervision is the way in which the need for World Bank support of the Chad/Cameroon oil pipeline was used as a lever to impose a range of governance conditionalities on Chad, notably the passage of a Revenue Management Law that specifies how funds from the pipeline will be spent (e.g., 80 percent of oil royalties were to be spent on poverty reduction programs). Another example is the Governance and Economic Management Assistance Program (GEMAP) introduced in postconflict Liberia in an attempt to address the pervasive corruption that has dogged successive Liberian governments. A key element in this program is the placing of international experts (or "foreign corruption spotters") in key positions inside major ministries and economic agencies such as the forestry commission and the Central Bank of Liberia to prevent the misuse of resources. ${ }^{11}$

However, local actors are often quite adept at deploying strategies of obstruction, evasion, or cooption of such initiatives. Moreover, a decline in dependence on external support may lead to renegotiation or outright rejection of supervision, particularly in a context where externals place rhetorical emphasis on both sovereignty and local ownership, and tend to suffer from a limited attention span anyway. Thus, once the oil came on tap in Chad the government passed a new law in 2005, ultimately accepted by the World Bank, permitting revenues to be spent on security and administration. In 2008, the World Bank withdrew from the project having concluded it would not achieve its original aims. Similarly, while GEMAP has achieved some short-term successes, Reno has noted how it is merely the latest in a succession of similar initiatives that ultimately had little effect: in 1998 for instance the United States sponsored an initiative that also put foreigners into government agencies. Goldfish-like Liberians, it would seem, are adept at sitting out emergency projects of social engineering and relying on the equal facility of donors to forget both their current ambitions for reform and the fact they have already been tried and failed anyway. ${ }^{12}$

Moreover, projects of economic supervision are framed as exceptional responses to local manifestations of pathologies supposedly common to all nonliberal forms of political economy and which in their local form threaten the security of citizens and externals alike. Thus, economic supervision depends for

its legitimization on a one-size-fits-all problematization (and securitization) of local governance and economy while also proffering a one-size-fits-all solution in the form of the liberal peace. Indeed, both the problematization of war economies and the emphasis on the imperative of transformation can be understood as speech acts that securitize and pathologize the local in order to legitimize the extraordinary measures deemed necessary to bring about liberal governance. ${ }^{13}$

The crude representations of both the problem and the solution are equally flawed. For example, certain forms of corruption may actually facilitate growth or provide stability, and even certain features of war economies can be engines of development. Part of the task of transforming political economies of conflict, then, is to avoid dismissing them as wholly dysfunctional and instead to identify the building blocks of peace and development existing inside local war economies. Furthermore, liberal projects of societal transformation imposed on postconflict societies can actually exacerbate features of poor governance, e.g., by introducing new opportunities for corruption linked to electoral or privatization processes, which can be further fanned by the unwillingness of donors to critique key economic or security allies. ${ }^{14}$

For some commentators the attempt to transform or prevent war economies via economic supervision has echoes of imperial imposition or can be understood as a strategy of biopolitics that aims to regulate the actions and transform the sensibilities of target populations, albeit under a simulacra of empowerment. Such analyses provide important insights into the politics underpinning economic supervision strategies. However, it is also important to recognize that the multiple strategies of cooption and resistance employed by local actors combine with selective strategies of accommodation on the part of externals to actually create hybrid forms of the liberal peace that, at least partly, frustrate the aims of external engineers. Moreover, these hybrids are often as problematic, as the modes of governance and economy they replace, with only temporary external instruments of pacification (troops and increases in aid) concealing this fact. Rather than concluding that local ownership and accountability therefore represent a prerequisite for the successful transformation of war economies, advocates of liberal intervention often view dysfunctional hybridity as a reason for even more extensive attempts to engineer liberal mimesis in the 
societies of the "other." 15

The combined effect is to leave projects of economic supervision looking more like examples of cognitive polyphasia on the part of externals who simultaneously invent more ambitious projects of reform while fetishizing sovereignty and local ownership, engaging in serial accommodation with local actors, and forgetting that their strategies have often been tried (and failed) before anyway.

\section{The production of forgetting}

In many respects the problem-solving debates over the appropriate balance between voluntarism, regulation, and economic supervision are fierce, as is the discussion on how best to reform the technicalities of initiatives such as EITI or Kimberley. Underpinning these fierce debates, however, is a shared understanding of the goal and direction of action. The goal is deemed to be the creation of frameworks that will transform economic actors capable of evincing the moral memory of goldfish into ethical elephants who never forget their broader obligations to state, society, and the international system. Moreover, whatever the nature of temporary setbacks, the direction of action is assumed to be ever onward and upward to the production of more extensive and more substantive ethical frameworks.

From a critical political economy perspective, however, the frameworks of voluntarism, regulation, and supervision, and indeed the dominance of the consensus, are better understood as cornerstones in an architecture of forgetting that functions in a number of ways and has a number of features. First, the assumption of linear advancement in ethical initiatives requires (and reinforces) extensive amnesia over the extent to which contemporary policies have either been recycled from past failures or actually represent a retreat from ethical regulation. In the first instance, programs for monitoring in Liberia, or as in Sierra Leone cooperative experiments that echo the push to promote cooperatives in the early $1950 \mathrm{~s}$, are presented as elements of a new, more progressive architecture of liberal intervention to transform war economies, rather than examples of history rhyming. Moreover, the ballooning of voluntary multi-stakeholder ethical trading initiatives in the post-cold war era is best understood as actually working to mask the general failure of attempts in the 1970s to impose meaningful constraints on corporate power and rebalance the relationship between the developed and developing world as part of Southern demands for a New International Economic Order. Thus, the 1974 U.N. Charter of Economic Rights and Duties of States had little effect as it was resisted by those countries with most jurisdiction over transnational corporations. The U.N. Center on Transnational Corporations (UNCTC), also established in the mid-1970s, was disbanded in the 1990s under pressure from Northern governments; the development of a Draft Code of Conduct on Transnational Corporations had stalled by the 1980s; and a similar initiative in the form of NGO pressure to make the 2003 U.N. Draft Norms on the Responsibilities of Transnational Corporations legally binding has been equally fruitless. In the main, those initiatives that have survived from the 1970s have tended to be the weaker, nonbinding agreements that emerged such as the OECD's Guidelines for Multinational Enterprises or the ILO's Tripartite Declaration of Principles Concerning Multinational Enterprises.

Second, the impression of frenetic ethical activity produced by the current plethora of initiatives obscures the failure to meaningfully address the various iniquities in the global trading system. These include declining terms of trade for low-income countries predominantly dependent on commodities for export and limited in their ability to add value in global trading systems such as that for diamonds - agricultural prices, for example, declined by 70 percent between 1961 and 2001. This problem has been further compounded by the adoption of various strategies to restrict market access to OECD countries while subsidized goods from developed world economies are dumped on the economies of aid supplicants required to open up their markets. In addition, the failure to circumscribe capital flight from the developing world and to take effective action against tax havens means that developing countries lose three times the value of aid provided by the developed world. At the same time, poverty reduction initiatives inside the developing world essentially constitute a relabeling of neoliberal macroeconomic policies emphasizing deregulation, privatization, lowering company taxes, reducing government wage bills, and integration into global markets. In contrast, in 2006 just USD88 million out of a total USD103 billion of aid from OECD countries was dedicated to tax-related tasks. $^{16}$

Third, the simulation of ethical action on both trade and war economies effectively functions as a form of misdirection that obscures the way current initiatives combine a problematic cocktail of disciplinary action aimed at particular pariah actors or goods with either ethical tokenism or simple neglect. Thus, while postconflict Liberia struggled with the legacy of diamond sanctions for four years, the reality is that most forms of conflict trade remain unregulated, uncertified, and unsanctioned. Indeed, there is not even an agreed international definition of what constitutes conflict trade. At the same time, however, the multiplication of tokenistic initiatives gives the impression that a high point of formal and informal ethical regulation has been reached. But it is instructive to compare the panoply of weak ethical trading initiatives with the regulatory frameworks deployed to defend the core principles of neoliberalism. For example, both states and firms face significant penalties for breaching free trade and competition requirements. Thus, the World Trade Organization permits states to impose quite substantial sanctions on other countries deemed to be engaging in anticompetitive practices; the European Union has imposed a series of fines amounting to EUR1.7 billion on Microsoft for breaching competition policy; while Shell had total fines of GBP85 million imposed on it by authorities in the United Kingdom and the United States for overstating its oil reserves and EUR161 million for its role in a cartel designed to fix the price of synthetic rubber. ${ }^{17}$ It might be argued that such fines are not that substantial when 
compared to the global sales of the firms involved. However, with the possible exception of Kimberley, they provide an embarrassing contrast to current action on the phenomenon of conflict trade.

Conclusion

The analysis presented here suggests that the current mix of voluntarism, regulation, and supervision is characterized by a drugs, thugs, and pariah bias that serves to discipline various weak, pariah, and nonstate actors rather than imposing regulation to transform war economies per se. Thus, on the one hand, the problematization of war economies serves to securitize the presumed pathologies of local governance and economy in order to legitimize the application of extraordinary measures designed to induce liberal mimesis inside weak and postconflict states, measures that are resisted in ways that actually produce dysfunctional hybrids of the liberal peace. On the other hand, on the outside of the weak and postconflict state, the apparent profusion of ethical action on conflict trade not only masks the failure to undertake substantive action to reform global structures that promote economies of conflict but significant elements of retreat from this goal. This is not to suggest that initiatives such as Kimberley or EITI are totally without merit; rather it is to suggest that even where individual initiatives achieve limited successes the broader structures of the global economy and the application of one-size-fits-all neoliberal prescriptions inside the weak and postconflict state militate against any substantive transformation. If the aim of action really is to encourage economic actors with a tendency for ethical amnesia to remember their broader responsibilities beyond narrow profit-making, then current action is more akin to training goldfish in a desert. However good individual training programs might be, the broader context in which they occur means they are ultimately destined to fail.

\section{Notes}

Neil Cooper is Senior Lecturer in International Relations and Security Studies, Department of Peace Studies, University of Bradford, Bradford, UK. He may be reached at r.n.cooper@bradford.ac.uk. A companion article appears as a chapter in Oliver Richmond, ed. Advances in Peace and Conflict Studies. London: Palgrave (forthcoming). This research benefitted from a grant by the U.K. Economic and Social Research Council (res. 223.25.0071) for research on the Transformation of War Economies (www.brad.ac.uk/acad/twe).

1. Ballentine and Nitzschke (2005); Ross (2004); Pugh and Cooper (2004).

2. Enlightened self-interest: e.g., Schwab (2008); empirical studies: e.g., Margolis and Walsh (2003).
3. On the GC, including membership, see http://www.unglobalcompact.org. Quotes from Ruggie (2007, p. 2) and Kell and Ruggie (2000, p. 20); number of transnational firms: Kell and Ruggie (2000, p. 6); complainants: Smith (2008, p. 15); noncommunicating: Global Compact (2007, p. 51); 6 percent: Smith (2008, p. 16).

4. EITI membership: Taylor (2008); bribes: "Former Head of Haliburton Firm Faces Seven Years in Jail for Bribery," The Guardian (London: 4 September 2008); Iraq, Burma, Somalia: U.S. Senate (2008, p. 66); World Bank: Global Witness (2008, p. 1); PWYP: Turner (2006, p. 375).

5. High-water mark: Lunde and Taylor (2005); KPCS quote: Smillie (2005, p.4); Côte d'Ivoire sanctions: letter dated 8 October 2008 from the Chairman of the Security Council Committee established pursuant to resolution 1572 (2004) concerning Côte d'Ivoire addressed to the President of the Security Council, New York: United Nations, S/2008/598, 9 October 2008, p. 33, para. 133; claim regarding conflict diamond world production: http://www.kimberleyprocess.com/faqs/index_en.html.

6. Seven occasions: Le Billon and Nicolls (2007, p. 620); vested interests: Lunde and Taylor (2005).

7. Quote: http://www.kimberleyprocess.com/documents/basic_core_documents _en.html.

8. Zimbabwe: see, e.g., the Partnership Africa Canada reports listed in the references; Israeli diamond exports: Office of the Diamond Controller, Facts and Figures: Diamonds, Precious Stones and Jewelry, 2006, and Ministry of Industry, Trade and Labor, Diamonds, Precious Stones and Jewelry Administration, Office of the Diamond Controller, May 2007; KPCS data on Israeli diamond exports: https://mmsd.mms.nrcan.gc.ca/kimberleystats/publicstats.asp; Israeli diamond export contribution to Israeli economy: Israel (2007).

9. Deterrence effect: Partnership Africa Canada (2008, p. 22); tax revenue effect: Partnership Africa Canada (2006); quote from: http://www.ddiglobal.org/pages/ddi_mission.php.

10. Sierra Leone's ceased cooperative projects, diggers' earnings, export earnings, tax revenues: Cooper (2008); Liberian tax revenues: Partnership Africa Canada (2007); quote: Zohar (2003); value-chain: DIB Online, "Chaim Even-Zohar Addresses Diamond Industry Issues at Mining Indaba Conference,” 5 February 2008 (http://www.diamondintelligence.com). 
(C) www.epsjournal.org.uk - Vol. 5, No. 1 (2010)

11. Royalties: Alexander and Gilbert (2008); “spotters": United Nations Integrated Regional Information Network, "Foreign Corruption Spotters Are Now in Place," 24 May 2006.

12. Reno (2008, p. 388).

13. Jennings (2008).

14. Corruption may facilitate: Reno (2008); Kang (2002); engines of development: Cramer (2006); exacerbation of poor governance: Le Billon (2008, p. 351).

15. Biopolitics: Duffield (2007); Chandler (2006); simulacra of empowerment: Pugh, Cooper, and Turner (2008, p. 391); dysfunctional hybridity: see, e.g., Krasner (2004).

16. Agricultural prices: Willett (2008, p. 70); aid: Gurria (2008).

17. The Guardian. "EU Fines Microsoft Record $£ 680 \mathrm{~m}$ 'to Close Dark Chapter' in Fight Against Monopoly." 28 February 2008; The Guardian. "Shell Faces New Damages Claim.” 10 January 2006.

\section{References}

Alexander, K. and S. Gilbert. 2008. Oil and Governance Report: A Case Study of Chad, Angola, Gabon, and Sao Tome é Principe. www.idasa.org.za/index.asp.

Ballentine, K. and H. Nitzschke. 2005. Profiting from Peace: Managing the Resource Dimensions of Civil War. Boulder, CO: Lynne Rienner.

Chandler, D. 2006. Empire in Denial: The Politics of State-building. London: Pluto. Cooper, N. 2008. “As Good As It Gets: Securing Diamonds in Sierra Leone,” pp. 103-115 in M. Pugh, N. Cooper, and M. Turner, eds. Whose Peace? Critical Perspectives on the Political Economy of Peacebuilding. Basingstoke, UK: Palgrave Macmillan.

Cramer, C. 2006. Civil War is Not a Stupid Thing: Accounting for Violence in Developing Countries. London: Hurst \& Company.

Duffield, M. 2007. Development, Security and Unending War: Governing the World of Peoples. Cambridge, UK: Polity.

Global Compact. 2007. United Nations Global Compact Annual Review, 2007. Leaders Summit. New York: United Nations Global Compact Office.

Global Witness and the Bank Information Center. 2008. "Assessment of International Monetary Fund and World Bank Group Extractive Industries Transparency Implementation." London: Global Witness.

Gurría, A. 2008. "The Global Dodgers." The Guardian. 27 November 2008

[Israel] 2007. Ministry of Industry, Trade and Labor. The Israeli Economy at a
Glance 2007. www.moital.gov.il/NR/exeres/C3969F21-C61D-4E23-90E9 5C7486E9029B.htm.

Jennings, K.M. 2008. "Securitizing the Economy of Reintegration in Liberia," pp. 157-170 in M. Pugh, N. Cooper, and M. Turner, eds. Whose Peace? Critical Perspectives on the Political Economy of Peacebuilding. Basingstoke, UK: Palgrave Macmillan.

Kang, D. 2002. Crony Capitalism: Corruption and Development in South Korea and the Philippines. New York: Cambridge University Press.

Kell, G. and J.G. Ruggie. 2000. "Reconciling Economic Imperatives with Social Priorities: The Global Compact." Paper presented at the Carnegie Council on Ethics and International Affairs, New York. 25 February 2000.

Krasner, S.D. 2004. "Sharing Sovereignty: New Institutions for Collapsed and Failing States.” International Security. Vol. 29, No. 2, pp. 85-120.

Le Billon, P. 2008. "Corrupting Peace? Peacebuilding and Post-Conflict Corruption." International Peacekeeping. Vol. 15, No. 3, pp. 344-361.

Le Billon, P. and E. Nicholls. 2007. "Ending 'Resource Wars': Revenue Sharing, Economic Sanction or Military Intervention?” International Peacekeeping. Vol. 14, No. 5, pp. 613-632.

Lunde, L. and M Taylor. 2005. "Regulating Business in Conflict Zones: Challenges and Options," pp. 317-343 in K. Ballentine and H. Nitzschke, eds. Profiting from Peace: Managing the Resource Dimensions of Civil War. Boulder, CO: Lynne Rienner.

Margolis, J.D. and J.P. Walsh. 2003. "Misery Loves Companies: Rethinking Social Initiatives by Business.” Administrative Science Quarterly. Vol. 48, Issue 2, pp. 268-305.

Partnership Africa Canada. 2006. Killing Kimberley? Conflict Diamonds and Paper Tigers. Occasional Paper No. 15. Revised edition. Ottawa.

Partnership Africa Canada. 2007. Land Grabbing and Land Reform: Diamonds, Rubber and Forests in the New Liberia. Occasional Paper No. 17. Ottawa.

Partnership Africa Canada. 2008. Diamonds and Human Security: Annual Review 2008. pacweb.org/e/index.php?option $=$ content\&task=view\&id=42\&Itemid $=65$.

Pugh, M. and N. Cooper (with J. Goodhand). 2004. War Economies in A Regional Context: The Challenges of Transformation. Boulder, Co: Lynne Rienner.

Pugh, M., N. Cooper, and M. Turner. 2008. Whose Peace? Critical Perspectives on the Political Economy of Peacebuilding. Basingstoke: Palgrave Macmillan.

Reno, W. 2008. "Anti-Corruption Efforts in Liberia: Are They Aimed at the Right Targets?” International Peacekeeping. Vol. 15, No. 3 (June), pp. 387-404.

Ross, M.L. 2004. "How do Natural Resources Influence Civil War? Evidence from Thirteen Cases.” International Organization. Vol. 58 (Winter), pp. 35-67.

Ruggie, J.G. 2007. "Business and Human Rights: The Evolving International Agenda." Corporate Social Responsibility Initiatives, Working Paper No 31, Cambridge, MA: John F. Kennedy School of Government, Harvard University. 
Schwab, K. 2008. "Global Corporate Citizenship: Working With Governments and Civil Society." Foreign Affairs. Vol. 87, No. 1, pp. 107-118.

Smillie, I. 2005. "The Kimberley Process Certification Scheme for Rough Diamonds." Verifor/Partnership Africa Canada.

www.verfor.org/resources/case-studies/kimberley-process.pdf.

Smith, J. 2008. "Power, Interests and the United Nations Global Compact." Paper presented at the International Studies Association Conference, San-Francisco, CA.

Taylor, S. 2008. "Resource Curse or Blessing: Africa's Management of its Extractive Industries." Hearing. United States Senate. Senate Foreign Relations Committee. $\mathrm{Subcommittee}$ on Africa. $24 \quad \mathrm{September}$. http//foreign.senate.gov/hearings/2008/hrg080924a.html.

Turner, M. 2006. "Taming Mammon: Corporate Social Responsibility and the Global Regulation of Conflict Trade." Conflict, Security and Development. Vol. 6, No. 3, pp. 365-387.

[U.S. Senate]. 2008. Report of the Minority Staff of the United States Senate, Committee on Foreign Relations. "The Petroleum and Poverty Paradox: Assessing US and International Community Efforts to Fight the Resource Curse." Draft. 9 September 2008.

http://lugar.senate.gov/sfrc/pdf/DRAFT_petroleum_poverty_paradox.pdf.

Willett, S. 2008. "Trading with Security: Trade Liberalisation and Conflict," pp. 6784 in M. Pugh, N. Cooper, and M. Turner, eds. Whose Peace? Critical Perspectives on the Political Economy of Peacebuilding. Basingstoke, UK: Palgrave Macmillan.

Zohar, C.E. 2003. "Sierra Leone Diamond Sector Financial Policy Constraints.” MSI for Peace Diamonds Alliance and USAID.

www.resourcebeneficiation.org/home.asp?id=12. 